\title{
PENGARUH DANA PIHAK KETIGA DAN EKUITAS TERHADAP LABA PADA BANK SYARIAH MANDIRI PERIODE 2012-2019
}

\author{
Kasmiri $^{1^{*}, \text { Kamal Nurjaman }}{ }^{2}$ \\ ${ }^{12}$ Fakultas Ekonomi dan Bisnis Islam, Universitas Suryakancana \\ *Corresponding Author e-mail: kasmiricampaka105@gmail.com

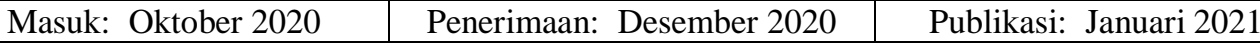

\begin{abstract}
ABSTRAK
Bank Syariah Mandiri sebagai lembaga keuangan terus berupaya menciptakan laba bersih dari setiap transaksi keuangan nasabahnya, sehingga upaya untuk menjaga perusahaan tetap memperoleh laba memerlukan evaluasi dari kedua instrumen keuangan bank di atas. Tujuan dari artikel ini yaitu untuk menganalisis seberapa besar pengaruh variabel Dana Pihak Ketiga dan variabel Ekuitas terhadap Laba pada Bank Syariah Mandiri Periode 2012-2019. Penelitian ini menggunakan pendekatan kuantitatif dengan metode deskriptif dan asosiatif. Data yang digunakan merupakan data sekunder yang bersumber dari data laporan keuangan triwulan Bank Syariah Mandiri periode tahun 2012 sampai 2019. Hasil penelitian menyimpulkan bahwa secara parsial Dana Pihak Ketiga (DPK) tidak berpengaruh signifikan terhadap Laba pada Bank Syariah Mandiri periode 2012-2019. Hal ini dapat dilihat pada hasil uji $\mathrm{t}$ (parsial) variabel $\mathrm{X}_{1}$ (DPK) diperoleh $\mathrm{t}$ hitung lebih kecil daripada $t$ tabel $(0,649<2,045)$, sedangkan Ekuitas berpengaruh signifikan terhadap Laba pada Bank Syariah Mandiri. Hal ini dapat dilihat pada hasil uji $\mathrm{t}$ (parsial) variabel $\mathrm{X}_{2}$ (Ekuitas) diperoleh thitung lebih besar daripada $t$ tabel $(2.120>2.045)$, dengan nilai signifikansi lebih kecil dari $0,05(0,043<0,05)$.Berdasarkan hasil uji $\mathrm{F}$, disimpulkan bahwa secara simultan DPK dan Ekuitas berpengaruh signifikan terhadap Laba Bank Syariah Mandiri periode 2012-2019. Hasil uji F (simultan) diperoleh Fhitung lebih besar daripada $\mathrm{F}$ tabel $(9.047>3.328)$ dengan nilai signifikansi lebih kecil daripada $0.05 \quad(0.001<0.05)$. Berdasarkan hasil uji koefisien determinasi $\left(\mathrm{R}^{2}\right)$, besarnya pengaruh DPK dan Ekuitas terhadap Laba Bank Syariah periode 2012-2019 sebesar $61 \%$ sedangkan sisanya sebesar $39 \%$ dipengaruhi variabel lainnya yang tidak diteliti dalam penelitian ini.
\end{abstract}

Kata Kunci: Dana Pihak Ketiga; Ekuitas; Laba; Performa Bank.

\begin{abstract}
Bank Syariah Mandiri as a financial institution continues to strive to create a net profit from each of its customers' financial transactions, so efforts to keep the company profitable requires an evaluation of the two bank financial instruments above. The purpose of this article is to analyze how much influence the Third Party Funds and Equity variables have on Profits at Bank Syariah Mandiri for the 2012-2019 period. This research uses a quantitative approach with descriptive and associative methods. The data used is secondary data sourced from Bank Syariah Mandiri quarterly financial report data for the period 2012 to 2019. The results of the study conclude that partially Third Party Funds (TPF) have no significant effect on Profits at Bank Syariah Mandiri for the period 2012-2019. This can be seen in the results of the $t$ test (partial) variable X1 (TPF) obtained t count smaller than t table $(0.649<2.045)$, while equity has a significant effect on
\end{abstract}


profit at Bank Syariah Mandiri. This can be seen in the results of the t test (partial) variable $X_{2}$ (Equity) obtained $t$ count greater than $t$ table (2.120> $2.045)$, with a significance value less than $0.05(0.043<0.05)$. Based on the results of the F test, it is concluded that simultaneously TPF and equity have a significant effect on the profit of Bank Syariah Mandiri for the period 2012-2019. The results of the F test (simultaneous) obtained Fcount greater than $F$ table $(9,047>3,328)$ with a significance value smaller than 0.05 $(0.001<0.05)$. Based on the test results of the coefficient of determination (R2), the effect of TPF and Equity on the Profit of Islamic Banks for the 2012-2019 period was $61 \%$ while the remaining $39 \%$ was influenced by other variables not examined in this study.

Keywords: Third Party Funds; Equity; Profits; Bank Performance.

\section{A. PENDAHULUAN}

Bank merupakan lembaga perantara keuangan (financial intermediaries) yang menyalurkan dana dari pihak kelebihan dana (surplus unit) kepada pihak yang membutuhkan dana (deficit unit) pada waktu yang ditentukan. Bank mempunyai fungsi sebagai penghimpun dan penyalur dana masyarakat. Dalam menjalankan fungsinya sebagai lembaga perantara, bank mendasarkan kegiatan usahanya pada kepercayaan masyarakat. Oleh karena itu, bank juga disebut sebagai lembaga kepercayaan masyarakat (agent of trust). Selain berfungsi sebagai agent of trust, bank juga berfungsi bagi pembangunan perekonomian nasional (agent of development) dalam rangka meningkatkan pemerataan, pertumbuhan ekonomi, dan stabilitas nasional.

Peningkatan total aset Bank Syariah Mandiri salah satunya didorong oleh penghimpunan dana pihak ketiga (DPK) sebagai indikator likuiditas. Dimana per September 2018, DPK Bank Syariah mandiri Rp 82,58 triliun dan naik sebesar 9,98\% menjadi Rp 90,94 triliun per september 2019. Nilai DPK (Dana Pihak Ketiga) ini merupakan dana terbesar yang dimiliki oleh Bank Syariah Mandiri. Hal ini sesuai dengan fungsi Bank Syariah Mandiri sebagai penghimpun dana dari masyarakat.

Dalam melakukan penghimpunan dana, Bank Syariah Mandiri membagi lima jenis penghimpunan dana yaitu giro wadiah, giro mudharabah, tabungan wadiah, tabungan mudharabah dan deposito mudharabah. Penghimpunan dana terbesar terdapat pada deposito mudharabah, namun pada deposito mudharabah ini nasabah juga mempertimbangkan keuntungan yang akan diperoleh. Faktor 
yang menjadi pertimbangan masyarakat menginvestasikan dananya di bank syariah adalah faktor return bagi hasil (Husaeni, 2016). Dengan demikian menjadi cukup penting bagi Bank Syariah Mandiri untuk tetap menjaga kualitas tingkat bagi hasil yang diberikan kepada nasabah. Jika tingkat bagi hasil terlalu rendah maka kepuasan nasabah menurun dan nasabah akan memindahkan dananya ke bank lain atau bank konvensional yang memiliki bunga yang lebih tinggi. Oleh karena itu secara tidak langsung tingkat bagi hasil menjadi faktor penentu Bank Syariah Mandiri dalam menghimpun dana pihak ketiga.

Menurut Malayu SP Hasibuan (2005: 3) bank berperan penting dalam mendorong perekonomian nasional karena bank merupakan pengumpul dana dari surplus unit dan penyalur kredit kepada defisit unit, tempat menabung yang efektif dan produktif bagi masyarakat, serta memperlancar lalulintas pembayaran bagi semua sektor perekonomian. Bank Syariah menjalankan kegiatan usahanya berdasarkan prinsip syariah dan menjauhi praktik riba. Industri perbankan syariah merupakan bagian dari sistem perbankan nasional yang mempunyai peranan penting dalam perekonomian Indonesia. Peranan perbankan syariah secara khusus antara lain sebagai perekat nasionalisme baru, artinya menjadi fasilitator jaringan usaha ekonomi kerakyatan, memberdayakan ekonomi umat, mendorong penurunan spekulasi di pasar keuangan, mendorong pemerataan pendapatan, dan peningkatan efisiensi mobilitas dana.

Menurut Baraba (2004: 5), bank syariah memiliki fungsi sebagai berikut: 1) Sebagai penerima amanah untuk melakukan investasi atas dana-dana yang dipercayakan oleh pemegang rekening investasi/ deposan atas dasar prinsip bagi hasil sesuai dengan kebijakan investasi bank; 2) Sebagai pengelola investasi atas dana yang dimiliki oleh pemilik dana/sahibul mal sesuai dengan arahan investasi yang dikehendaki oleh pemilik dana (dalam hal ini bank bertindak sebagai manajer investasi); 3) Sebagai penyedia jasa lalu lintas pembayaran dan jasa-jasa lainnya sepanjang tidak bertentangan dengan prinsip syariah; 4) Sebagai pengelola fungsi sosial seperti pengelolaan dana zakat dan penerimaan serta penyaluran dana kebajikan (fungsi opsional). Selain itu konsep perbankan syariah mengharuskan bank-bank Islam untuk memainkan peran penting didalam 
pengembangan sumber daya manusianya dan memberikan kontribusi bagi kesejahteraan sosial.

Menurut Sadono Sukimo (2012: 263), salah satu tujuan didirikannya suatu perusahaan adalah untuk memperoleh laba atau profit. Laba atau profit merupakan pengembalian modal yang diperoleh perusahaan dari hasil investasi yang dilakukan dalam suatu periode fiskal, dimana profit yang dihasilkan mencerminkan efektifitas operasional perusahaan dalam menjalankan kinerjanya, sehingga profit dapat dijadikan indikator pencapaian kinerja perusahaan yang baik.

Profit perusahaan dapat didistribusikan untuk beberapa kegunaan, yaitu sebagai tambahan untuk modal yang sedang berjalan, sebagai dividen pemegang saham, sebagai dana cadangan dalam perusahaan ataupun diinvestasikan dalam pasar saham. Perusahaan bisnis yang bergerak dengan dukungan moral agama seperti bank syariah, merupakan potensi bagi perusahaan untuk menarik lebih tinggi minat masyarakat muslim (Husaeni, 2018), dimana keuntungan kelembagaan menjalankan bisnis di sektor perbankan berbanding lurus dengan dorongan moral individu untuk mendapatkan ketenangan jiwa disebabkan panduan agama untuk bertransaksi yang halal dan tidak mengandung bunga (riba).

Menurut Sofyan Syafri Harahap (2010: 304), dalam upaya memperoleh laba yang maksimal, bank syariah memegang prinsip-prinsip syariat dalam mengelola aset dan memegang kepercayaan nasabah berupa tanggung jawab pemenuhan kewajibannya sebagai lembaga yang sangat bergantung dari asas kepercayaan. Selain diukur dengan pendekatan pengelolaan aset, upaya menghasilkan laba juga memperhatikan aspek manajemen bank seperti mengoptimalkan sumber daya yang dimiliki bank, pemasaran layanan produk yang laku, penyaluran pembiayaan dan kas yang lancar, modal yang kuat, jumlah karyawan, jumlah kantor cabang dan evaluasi kinerja yang dipasarkan kepada calon nasabah dalam bentuk produk.

Diantara beberapa faktor yang mempengaruhi jumlah laba yang diterima Bank Syariah adalah jumlah dana pihak ketiga yang mampu dihimpun bank, dimana semakin besar dana nasabah yang dihimpun produk bank syariah maka aset yang dimiliki pun akan semakin besar yang dapat digunakan untuk 
menyalurkan pembiayaan dan sebagai salah satu tolak ukur kesehatan bank. Faktor lainnya yang berpengaruh terhadap perolehan laba adalah pembiayaan yang disalurkan bank, dimana semakin besar pembiayaan yang disalurkan bank syariah maka margin bagi hasil yang diterima pihak bank juga semakin besar (Husaeni, 2017). Hal ini merupakan motivasi untuk bank syariah agar mampu menjalankan pembiayaan yang lancar dan terpercaya. Faktor terakhir yang mempengaruhi laba adalah modal yang dimiliki bank, dimana semakin besar jumlah modal yang ada maka semakin kuat keuangan bank syariah, semakin banyak dana yang bisa digunakan untuk penyaluran pembiayaan dan sebagai salah satu tolak ukur kesehatan bank.

Menurut Mardhiyyah Fitria Ekawati (2010: 27), dana pihak ketiga sangatlah penting bagi bank dalam menghimpun dana, karena pada dasarnya untuk kepentingan usahanya bank menghimpun dana dari bank itu sendiri, dana yang berasal dari pihak lain, dan dana yang berasal dari masyarakat atau pihak ketiga yang berupa tabungan deposit serta sumber dana lainnya. Dana pihak ketiga adalah dana-dana yang berasal dari masyarakat, baik perorangan maupun badan usaha, yang diperoleh bank dengan menggunakan berbagai instrumen produk simpanan yang dimiliki oleh bank.

Selanjutnya, pembiayaan adalah penyediaan uang berdasarkan kesepakatan antara bank dengan nasabah untuk mengembalikan uang tersebut setelah jangka waktu tertentu dengan imbalan. Pembiayaan merupakan aktivitas lainnya yang sangat penting dalam perbankan. Dengan adanya pembiayaan akan diperoleh sumber pendapatan utama dan menjadi penunjang kelangsungan usaha suatu bank.

Ekuitas merupakan bagian dari dana yang dapat digunakan bank dalam aktivitas kesehariannya. Modal merupakan faktor yang amat penting bagi perkembangan dan kemajuan bank sekaligus menjaga kepercayaan masyarakat. Modal bank adalah dana yang diinvestasikan oleh pemilik dalam rangka pendirian badan usaha yang dimaksudkan untuk membiayai kegiatan usaha bank disamping untuk memenuhi regulasi yang ditetapkan oleh otoritas moneter (Husaeni, 2017).

Salah satu perusahaan di bidang perbankan syariah adalah Bank Syariah Mandiri yang resmi menjalankan kantor yang beroperasional syariah pada 19 Juni 
2010 sebagai bank umum syariah. Sebagai sebuah perusahaan bisnis maka Bank

Syariah Mandiri sangat memperhatikan efektifitas dan efisiensi pengelolaan assetnya dalam menghasilkan laba. Laba Bank Mandiri Syariah akan ditentukan dari akumulasi capaian kinerja baik dari faktor internal maupun faktor eksternal bank, dimana produk-produk seperti besarnya jumlah dana pihak ketiga dan ekuitas akan menentukan capaian operasional bank di akhir tahun. Kondisi keuangan Bank Syariah Mandiri pada periode tahun 2012-2019 dapat dilihat dalam tabel berikut:

Tabel 1

Jumlah Dana Pihak Ketiga, Ekuitas terhadap Laba Bank Syariah Mandiri periode 20122019 (dalam Jutaan Rupiah)

\begin{tabular}{|c|c|c|c|c|}
\hline Tahun & Triwulan & $\begin{array}{l}\text { DPK } \\
\text { (Rp) }\end{array}$ & $\begin{array}{c}\text { Ekuitas } \\
\text { (Rp) }\end{array}$ & $\begin{array}{l}\text { Laba } \\
\text { (Rp) }\end{array}$ \\
\hline \multirow{4}{*}{2012} & I & 5.010 .795 & 1.098 .431 & 40.544 \\
\hline & II & 5.079 .950 & 1.080 .385 & 52.494 \\
\hline & III & 5.274 .430 & 1.113 .941 & 91.086 \\
\hline & IV & 5.550 .985 & 1.076 .677 & 72.386 \\
\hline \multirow{4}{*}{2013} & I & 7.539 .344 & 1.080 .984 & 82.975 \\
\hline & II & 7.537 .374 & 1.106 .362 & 93.421 \\
\hline & III & 7.638 .027 & 1.145 .329 & 144.329 \\
\hline & IV & 8.570 .242 & 1.187 .218 & 101.892 \\
\hline \multirow{4}{*}{2014} & I & 10.150 .780 & 1.222 .215 & 221.215 \\
\hline & II & 10.642 .514 & 1.241 .639 & 240.637 \\
\hline & III & 10.819 .758 & 1.273 .875 & 272.875 \\
\hline & IV & 11.071 .780 & 1.304 .680 & 117.462 \\
\hline \multirow{4}{*}{2015} & I & 3.098 .252 & 1.339 .183 & 34.503 \\
\hline & II & 6.813 .418 & 1.371 .161 & 66.481 \\
\hline & III & 10.788 .421 & 1.909 .111 & 103.931 \\
\hline & IV & 15.032 .391 & 1.950 .000 & 163.251 \\
\hline \multirow{4}{*}{2016} & I & 4.514 .821 & 1.995 .667 & 45.668 \\
\hline & II & 9.055 .240 & 2.049 .942 & 99.943 \\
\hline & III & 13.849 .888 & 2.106 .618 & 156.619 \\
\hline & IV & 18.836 .095 & 2.215 .658 & 265.658 \\
\hline \multirow{4}{*}{2017} & I & 5.215 .929 & 2.290 .836 & 75.178 \\
\hline & II & 10.778 .503 & 2.361 .468 & 145.645 \\
\hline & III & 27.579 .599 & 2.429 .873 & 214.215 \\
\hline & IV & 25.483 .778 & 2.486 .566 & 270.908 \\
\hline \multirow{4}{*}{2018} & I & 26.759 .667 & 2.576 .968 & 77.638 \\
\hline & II & 27.832 .935 & 2.667 .837 & 165.083 \\
\hline & III & 28.389 .802 & 2.755 .869 & 269.302 \\
\hline & IV & 32.587 .200 & 3.807 .298 & 320.732 \\
\hline \multirow{4}{*}{2019} & I & 55.455 .352 & 3.901 .128 & 93.831 \\
\hline & II & 62.949 .515 & 3.997 .599 & 190.302 \\
\hline & III & 65.436 .012 & 4.097 .072 & 289.775 \\
\hline & IV & 68.690 .389 & 4.242 .166 & 434.868 \\
\hline
\end{tabular}

Sumber: Laporan Keuangan Triwulan Bank Mandiri Syariah Tahun 2012-2019 (data diolah) 
Dari data Tabel 1 di atas dapat dilihat bahwa pertumbuhan laba Bank Syariah Mandiri mengalami penurunan pada tahun 2012 triwulan IV, tahun 2013 triwulan IV dan tahun 2014 triwulan IV. Secara teori dana pihak ketiga memiliki hubungan searah dengan laba. Tetapi dari Table 1 di atas pertumbuhan laba dengan dana pihak ketiga tidak memiliki hubungan searah. Pada tahun 2012 triwulan IV pertumbuhan dana pihak ketiga naik sebesar Rp 5.550.985, sedangkan pertumbuhan laba menurun menjadi Rp 72.386 juta. Pada tahun 2013 triwulan IV pertumbuhan dana pihak ketiga naik sebesar Rp 8.570.242 juta, sedangkan pertumbuhan laba menurun menjadi Rp 101.892 juta. Pada tahun 2014 triwulan IV pertumbuhan dana pihak ketiga naik sebesar Rp 11.071.780 juta, sedangkan pertumbuhan laba menurun menjadi Rp 117.462 juta.

Berdasarkan uraian di atas dan memperhatikan gambaran perkembangan kaitan dana pihak ketiga dan ekuitas dengan peroleh laba seperti tersaji dalam Tabel 1, peneliti tertarik untuk meneliti pengaruh dana pihak ketiga dan ekuitas terhadap laba bersih pada Bank Syariah Mandiri periode 2012-2019.

\section{B. METODE PENELITIAN}

Penelitian ini menggunakan pendekatan kuantitatif dengan metode asosiatif. Populasi dalam penelitian ini adalah data Laporan Keuangan Bank Syariah Mandiri Indonesia selama periode tahun 2012 sampai tahun 2019. Teknik penetapan sampel yang dilakukan peneliti dengan pertimbangan khusus (purposive sampling), yaitu teknik penentuan sampel dengan pertimbangan khusus sehingga layak dijadikan sampel (Sugiyono, 2011: 85).

Penarikan sampel dengan teknik tersebut, dilakukan dengan pertimbangan sebagai berikut: 1) Bank syariah mandiri yang sudah mempublikasikan laporan keuangan tahun 2012 sampai dengan tahun 2019; 2) Bank Syariah Mandiri laporan keuangannya sudah teraudit BI; 3) Bank syariah mandiri sudah memiliki data yang terkait pembiayaan Mudharabah dan pembiayaan Murabahah.selama periode tahun 2012 sampai dengan tahun 2019.

Teknik analisis data yang digunakan dalam penelitian ini adalah dengan melakukan analisis kuantitatif yang dinyatakan dengan angka-angka yang dalam perhitungannya menggunakan metode statistic yang dibantu dengan program 
pengolah data statistic SPSS versi 20. Metode-metode analisis yang digunakan mencakup uji statistik deskriptif, uji asumsi klasik, analisis regresi berganda, uji koefisien determinasi R2, dan uji signifikansi parsial individual (uji statistik t), dan uji signifikansi simultan (uji statistik F).

\section{PEMBAHASAN DAN HASIL PENELITIAN}

Berdasarkan hasil olah data statistik, ditemukan bahwa DPK tidak berpengaruh signifikan terhadap laba pada Bank Syariah Mandiri.

Tabel 2

Hasil Uji t (Parsial)

\begin{tabular}{|c|c|c|c|c|c|c|}
\hline \multicolumn{7}{|c|}{ Coefficients $^{\mathrm{a}}$} \\
\hline \multirow{2}{*}{\multicolumn{2}{|c|}{ Model }} & \multicolumn{2}{|c|}{ Unstandardized Coefficients } & $\begin{array}{l}\text { Standardized } \\
\text { Coefficients }\end{array}$ & \multirow[b]{2}{*}{$\mathrm{t}$} & \multirow[b]{2}{*}{ Sig. } \\
\hline & & B & Std. Error & Beta & & \\
\hline \multirow[t]{3}{*}{1} & (Constant) & 40842.371 & 98100.279 & & .416 & .680 \\
\hline & DPK & .045 & .018 & .426 & 2.420 & .022 \\
\hline & EKUITAS & .048 & .017 & .498 & 2.825 & .008 \\
\hline \multicolumn{7}{|c|}{ a. Dependent Variable: LABA } \\
\hline
\end{tabular}

Sumber: Hasil Olah Data SPSS 24, 2019

Hal ini terlihat dari hasil uji t (parsial) variabel X1 (DPK) diperoleh nilai thitung sebesar 2,420 dengan signifikansi 0,022. Nilai signifikansi ini lebih kecil dari $0,05(0,022<0,05)$. Dengan demikian, dapat disimpulkan bahwa DPK berpengaruh signifikan terhadap laba pada Bank Syariah Mandiri tahun 20122019. Sedangkan, hasil uji t (parsial) variabel X1 (DPK) diperoleh nilai thitung sebesar 2,825 dengan signifikansi 0,008. Nilai signifikansi ini lebih kecil dari 0,05 $(0,008<0,05)$. Dengan demikian, dapat disimpulkan bahwa ekuitas berpengaruh signifikan terhadap laba pada Bank Syariah Mandiri.

Analisis data dan pengujian hipotesis dalam penelitian ini akan dilakukan dengan menggunakan model regresi linier berganda, dimana dalam analisis regresi tersebut akan menguji pengaruh Dana Pihak Ketiga $\left(\mathrm{X}_{1}\right)$ dan Ekuitas $\left(\mathrm{X}_{2}\right)$ terhadap Laba Bersih (Y). Pengolahan data menggunakan bantuan program komputer SPSS versi 24, 2019 berdasarkan data-data yang diperoleh dari laporan keuangan Bank Syariah Mandiri. Hasil analisis regresi linear berganda tersaji dalam tabel berikut ini. 
Tabel 4.6

Hasil Analisis Regresi Linier Berganda

\begin{tabular}{|c|c|c|c|c|c|c|}
\hline \multicolumn{7}{|c|}{ Coefficients $^{\mathrm{a}}$} \\
\hline & & \multicolumn{2}{|c|}{ Unstandardized Coefficients } & $\begin{array}{l}\text { Standardized } \\
\text { Coefficients }\end{array}$ & \multirow[b]{2}{*}{$\mathrm{t}$} & \multirow[b]{2}{*}{ Sig. } \\
\hline \multicolumn{2}{|c|}{ Model } & $\mathrm{B}$ & Std. Error & Beta & & \\
\hline \multirow[t]{3}{*}{1} & (Constant) & 40842.371 & 98100.279 & & .416 & .680 \\
\hline & DPK & .045 & .018 & .426 & 2.420 & .022 \\
\hline & EKUITAS & .048 & .017 & .498 & 2.825 & .008 \\
\hline
\end{tabular}

a. Dependent Variable: LABA

Sumber: Hasil Olahan Data SPSS 24,2019

Dari Tabel 4.6 di atas, Hasil analisis regresi berganda diperoleh koefisien untuk variabel bebas $X_{1}=0,045 X_{2}=0,048$ dengan konstanta -40842.371 . Dengan demikian, model persamaan regresi yang diperoleh adalah:

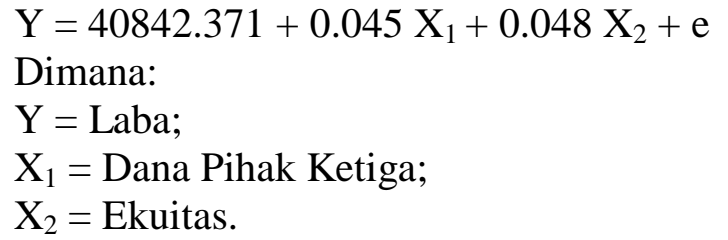

Berdasarkan persamaan regresi linear berganda diatas, maka dapat di interprestasikan sebagai berikut: a) Nilai Konstanta sebesar 40842.371 menyatakan bahwa jika variabel independen dianggap konstan, maka rata-rata Laba yang didapatkan sebesar 40842.371 ; b) Koefisien regresi $\mathrm{X}_{1}$ (DPK) dari perhitungan linier berganda dapat dilihat 0.045 persen, hal ini berarti setiap ada peningkatan satu persen maka Laba yang didapatkan juga akan naik sebesar 0,045 persen; c) Koefisien regresi $\mathrm{X}_{2}$ (Ekuitas) sebesar 0.048, hal ini berarti setiap ada peningkatan satu persen maka Laba Bersih yang didapatkan akan naik sebesar 0.048 persen.

Selanjutnya dilakukan Uji koefisien determinasi atau R2 bertujuan untuk mengetahui seberapa besar kemampuan variabel independen/bebas (DPK dan Ekuitas) menjelaskan variabel dependen terikat (Laba) atau untuk mengetahui besar persentase pengaruh terhadap variabel terikat yang dijelaskan oleh variabel bebas. 
Tabel 3

Hasil Uji Koefisien Determinasi $\left(\mathbf{R}^{2}\right)$

Model Summary

\begin{tabular}{|l|r|r|r|c|}
\hline Model & R & R Square & $\begin{array}{c}\text { Adjusted R } \\
\text { Square }\end{array}$ & $\begin{array}{c}\text { Std. Error of the } \\
\text { Estimate }\end{array}$ \\
\hline 1 & $.504^{\mathrm{a}}$ & .254 & .203 & 190426.56190 \\
\hline \multicolumn{2}{|l|}{ a. Predictors: (Constant), EKUITAS, DPK } \\
\hline
\end{tabular}

Sumber: Hasil Olahan Data SPSS Versi 24, 2019

Dari Tabel 4.7, hasil uji $\mathrm{R}^{2}$ diperoleh hasil besarnya nilai $\mathrm{R}$ Square dalam model regresi ini peroleh sebesar 0,254. Sehingga nilai koefisien determinasi yang diperoleh adalah sebagai berikut:

$$
\begin{aligned}
& \mathrm{KP}=\mathrm{r}^{2} \times 100 \% \\
& \mathrm{KD}=0,254 \times 100 \% \\
& =25,4 \%
\end{aligned}
$$

Hal ini menunjukkan bahwa kemampuan menerangkan variabel Dana Pihak Ketiga dan Ekuitas terhadap Laba dipengaruhi oleh model persamaan ini sebesar $25,4 \%$ sedangkan sisanya sebesar 74,6\% dipengaruhi oleh faktor-faktor lain diluar variabel yang diteliti. Untuk mengetahui seberapa besar kontribusi (\%) pengaruh yang diberikan variabel independen $\left(X_{1}\right.$ dan $\left.X_{2}\right)$ terhadap variabel dependen (Y) maka dapat dihitung menggunakan metode sumbangan efektif (SE). SE adalah ukuran sumbangan suatu variabel independen terhadap variabel dependen dalam analisis regresi. Penjumlahan dari sumbangan efektif untuk semua variabel independen adalah sama dengan jumlah nilai yang ada pada koefisien determinasi atau $\mathrm{R}$ Square $\left(\mathrm{R}_{2}\right)$. Berikut ini tersaji tabel dan rumus untuk menghitung SE dari variabel independen $\mathrm{X}_{1}$ dan $\mathrm{X}_{2}$ :

Tabel 4

Perhitungan Sumbangan Efektif (SE)

\begin{tabular}{|c|c|c|c|}
\hline Variabel & $\begin{array}{c}\text { Koefisisen } \\
\text { Regresion Beta }\end{array}$ & Koefisien Korelasi & \multirow{2}{*}{ R Square } \\
\hline $\mathrm{X}_{1}$ & 0,426 & 0,221 & \multirow{2}{*}{$25,4 \%$} \\
\hline $\mathrm{X}_{2}$ & 0,498 & 0,322 & \\
\hline
\end{tabular}

Sumber: Data diolah oleh peneliti

Dari data tabel 4.8 digunakan untuk melakukan perhitungan SE dengan menggunakan rumus sebagai berikut: 
SE (X) $\%=$ Beta $_{\mathrm{x}}$ X Koefisien X 100\%

ATAU

SE $(X) \%=$ Betax X rxy X 100\%

Perhitungan sumbangan efektif variabel Dana Pihak Ketiga (X1) terhadap Laba (Y) sebagai berikut:

$\mathrm{SE}\left(\mathrm{X}_{1}\right) \%=\operatorname{Beta}_{\mathrm{x} 1} \mathrm{X} \mathrm{r}_{\mathrm{xy}} \mathrm{X} 100 \%$

SE $\left(X_{1}\right) \%=0,426 \times 0,221 \times 100 \%$

$\operatorname{SE}\left(\mathrm{X}_{1}\right) \%=9,4 \%$

Hasil perhitungan $\mathrm{SE} \mathrm{X}_{1}$ ini menunjukkan kotribusi atau pengaruh variabel Dana Pihak Ketiga $\left(\mathrm{X}_{1}\right)$ terhadap Laba $(\mathrm{Y})$ sebesar $9,4 \%$. Sedangkan perhitungan sumbangan efektif variabel Ekuitas (X2) terhadap Laba (Y) sebagai berikut:

$\mathrm{SE}\left(\mathrm{X}_{2}\right) \%=\operatorname{Betax}_{2} \mathrm{X}_{\mathrm{xy}} \mathrm{X} 100 \%$

$\operatorname{SE}\left(\mathrm{X}_{2}\right) \%=0,498 \times 0,322 \times 100 \%$

$\mathrm{SE}\left(\mathrm{X}_{2}\right) \%=16 \%$

Hasil perhitungan $\mathrm{SE} \mathrm{X}_{2}$ ini menunjukkan kontribusi atau pengaruh variabel Ekuitas $\left(\mathrm{X}_{2}\right)$ terhadap variabel Laba $(\mathrm{Y})$ sebesar 16\%. Sumbangan Efektif (SE) total antara variabel Dana Pihak Ketiga dan Ekuitas terhadap Laba sebagai berikut:

$\mathrm{SE}$ total $=\mathrm{SE}\left(\mathrm{X}_{1}\right) \%+\mathrm{SE}\left(\mathrm{X}_{2}\right) \%$

$\mathrm{SE}$ total $=9,4 \%+16 \%=25,4 \%$

Kesimpulan, berdasarkan hasil perhitungan diatas dapat diketahui bahwa SE variabel Dana Pihak Ketiga $\left(\mathrm{X}_{1}\right)$ terhadap Laba $(\mathrm{Y})$ sebesar 9,4 persen, sementara SE variabel Ekuitas $\left(\mathrm{X}_{2}\right)$ terhadap Laba $(\mathrm{Y})$ sebesar 16 persen. Dengan demikian dapat disimpulkan bahwa variabel Ekuitas $\left(\mathrm{X}_{2}\right)$ memiliki pengaruh lebih dominan terhadap variabel Laba $(\mathrm{Y})$ dari pada variabel Dana Pihak Ketiga $\left(\mathrm{X}_{1}\right)$. Untuk SE total sebesar 25,4 persen atau sama dengan koefisien determinasi ( $R$ Square) analisis regresi yaitu sebesar 25,4 persen.

\section{Pengaruh Dana Pihak Ketiga (DPK) Terhadap Laba}

Sesuai dengan rumusan masalah dengan hipotesis yang digunakan peneliti adalah sebagai berikut: $\mathrm{H}_{\mathrm{o} 1}$ : Dana Pihak Ketiga (DPK) secara parsial tidak berpengaruh signifikan terhadap laba. Berdasarkan hasil olah data statistik, ditemukan hasil penelitian bahwa DPK tidak berpengaruh signifikan terhadap 
laba pada Bank Syariah Mandiri. Hal ini terlihat dari hasil uji t (parsial) variabel

$\mathrm{X}_{1}$ (DPK) diperoleh $t_{\text {hitung }}$ sebesar 2,420 dengan signifikansi 0,022. Nilai signifikansi lebih kecil dari 0,05 $(0,022<0,05)$. Demikian pula, diperoleh thitung lebih kecil dari $t_{\text {tabel }}(2,420<2,045)$ sehingga $\mathrm{H}_{\mathrm{a} 1}$ diterima dan $\mathrm{H}_{\mathrm{o} 1}$ ditolak. Oleh karena itu, dapat disimpulkan bahwa DPK berpengaruh signifikan terhadap laba pada Bank Syariah Mandiri tahun 2012-2019. Berdasarkan Nilai koefisien regresi dari hasil perhitungan regresi berganda mempunyai tanda positif, artinya jika DPK naik maka laba bersihjuga ikut naik. Hal ini dapat disimpulkan bahwa DPK merupakan salah satu komponen variabel yang mempengaruhi besarnya laba.

Hasil penelitian ini memperkuat hasil penelitian terdahulu yang dilakukan oleh Fauziah Durotul Masruroh (2018) yang meneliti tentang pengaruh Dana Pihak Ketiga (DPK) dan Jumlah Pembiayaan terhadap Laba BNI Syariah yang menyimpulkan bahwa Dana Pihak Ketiga berpengaruh terhadap Laba BNI Syariah. Dalam penelitian ini, ditemukan secara parsial bahwa DPK berpengaruh signifikan terhadap laba, maka hipotesis Hal diterima. Hasil penelitian ini mengindikasikan bahwa peningkatan DPK selama periode penelitian mempengaruhi laba secara signifikan.Dengan demikian, maka semakin tinggi DPK yang berhasil dihimpun oleh perbankan, akan mampu mendorong peningkatan jumlah laba yang diperoleh.Hal itu terjadi karena laba dari penyaluran DPK akan berpotensi meningkat.

Penyaluran dana menjadi prioritas utama bank dalam pengalokasian dananya. Hal ini dikarenakan sumber dana bank berasal dari masyarakat sehingga bank harus menyalurkan kembali DPK yang berhasil dihimpun kepada masyarakat dalam bentuk pembiayaan. Hal ini sejalan dengan fungsi bank sebagai perantara keuangan (financial intermediary). Disamping itu penyaluran dana merupakan aktivitas yang paling utama bagi Bank selaku business entity dalam menghasilkan keuntungan. Pengalaman dan kemampuan yang dimiliki juga turut mendukung keberanian Bank dalam menyalurkan dana.

\section{Pengaruh Ekuitas Terhadap Laba}

Sesuai dengan rumusan masalah dengan hipotesis yang diajukan peneliti adalah sebagai berikut: $\mathrm{H}_{\mathrm{a} 2}$ : Ekuitas secara parsial berpengaruh signifikan 
terhadap laba. Berdasarkan hasil olah data statistik, ditemukan bahwa Ekuitas berpengaruh signifikan terhadap Laba pada Bank Syariah Mandiri. Hal ini dapat dilihat dari hasil uji t (parsial) variabel $\mathrm{X}_{2}$ (Ekuitas) diperoleh thitung sebesar 2,825 dengan signifikansi 0,008. Nilai signifikansi lebih kecil dari 0,05 (0,008< 0,05). Demikian pula, $t_{\text {hitung }}$ lebih besar dari $t$ tabel $(2,825>2,045)$, sehingga $\mathrm{H}_{\mathrm{a} 2}$ diterima dan $\mathrm{H}_{\mathrm{o} 2}$ ditolak. Oleh karena itu, dapat disimpulkan Ekuitas berpengaruh signifikan terhadap Laba pada Bank Syariah Mandiri tahun 2012-2019. Nilai koefisien regresi dari hasil perhitungan regresi berganda mempunyai tanda positif, artinya jika Ekuitas naik maka laba juga ikut naik. Hal ini dapat disimpulkan bahwa Ekuitas adalah salah satu komponen variabel yang mempengaruhi besarnya laba.

Hasil penelitian ini sejalan dengan hasil penelitian terdahulu yang dilakukan oleh Zahroh Naimah (2006) yang meneliti tentang pengaruh ukuran perusahaan dan ekuitas terhadap laba pada PT BNI Syariah. Variabel dalam penelitian ini adalah dana ukuran perusahaan, ekuitas dan laba. Hasil penelitian menunjukkan bahwa ekuitas berpengaruh positif signifikan terhadap laba Bank Syariah Mandiri di Indonesia.

Dari hasil perhitungan secara parsial diperoleh bahwa ekuitas berpengaruh signifikan terhadap laba bersih, maka hipotesis $\mathrm{H}_{\mathrm{a} 2}$ diterima dan menolak $\mathrm{H}_{\mathrm{o} 2}$. Hasil penelitian ini mengindikasikan bahwa peningkatan atau penurunan ekuitas selama periode penelitian mempengaruhi laba secara signifikan. Maka semakin tinggi ekuitas yang dimiliki oleh perbankan, akan mendorong peningkatan jumlah laba yang diperoleh, hal itu disebabkan ekuitas sebagai dasar bagi penetapan batas maksimum pemberian pembiayaan.

\section{Pengaruh Dana Pihak Ketiga (DPK) dan Ekuitas Terhadap Laba}

Sesuai dengan rumusan masalah dengan hipotesis yang diajukan peneliti yaitu: $\mathrm{H}_{\mathrm{a} 3}$ : Dana Pihak Ketiga (DPK) dan Ekuitas secara simultan berpengaruh signifikan terhadap laba pada Bank Syariah Mandiri Periode 2012-2019. Berdasarkan hasil uji F, menunjukkan bahwa DPK dan Ekuitas secara simultan berpengaruh signifikan terhadap laba pada Bank Syariah Mandiri periode 20122019. Hal ini dapat dilihat dari nilai $F$ hitung lebih besar daripada $F$ tabel (4.939> 3.328), dengan nilai signifikansi 0,014 lebih kecil dari pada $0.05(0,014<0,05)$. 
Dengan demikian $\mathrm{H}_{\mathrm{a} 3}$ diterima dan $\mathrm{H}_{\mathrm{o} 3}$ ditolak. Hal ini berarti DPK dan Ekuitas berpengaruh signifikan terhadap Laba pada Bank Syariah Mandiri Periode 20122019. Dari hasil perhitungan regresi berganda, nilai koefsien mempunyai tanda positif, artinya jika DPK dan Ekuitas naik maka Laba juga ikut naik. Hal ini dapat disimpulkan bahwa DPK dan Ekuitas adalah salah satu komponen variabel yang mempengaruhi besarnya Laba.

Hasil penelitian ini memperkuat hasil penelitian terdahulu yang dilakukan oleh Mardiyyah Fitria Ekawati (2010) tentang Pengaruh Dana Pihak Ketiga (DPK) dan Modal Disetor Terhadap Laba Bank Umum Syariah di Indonesia yang menyimpulkan bahwa variabel DPK berpengaruh terhadap Laba. Berdasarkan hasil uji koefisien determinasi $\left(\mathrm{R}_{2}\right)$ dan sumbangan efektif (SE) besarnya pengaruh variabel DPK dan Ekuitas terhadap Laba Bank Syariah Mandiri periode 2012-2019 adalah sebesar 25,4\%, sisanya 74,6\% merupakan pengaruh dari variabel lainnya yang tidak diteliti dalam penelitian ini.

Dalam kegiatan operasional perbankan, penyaluran dana menjadi prioritas utama. Oleh karena itu, DPK menjadi faktor penting dalam menjalankan tugas dan fungsi bank sebagai perantara keuangan (financial intermediary). Disamping itu penyaluran dana merupakan aktivitas yang paling utama bagi Bank selaku business entity untuk menghasilkan laba dari penyaluran uang melalui kegiatan pembiayaan terhadap nasabah. Dalam pandangan syariah, uang bukanlah merupakan komoditi yang dijadikan alat untuk mencapai pertumbuhan nilai ekonomi. Uang harus dikaitkan dengam kegiatan ekonomi primer (primary economic aktivities) baik manufaktur, sewa-menyewa dan lain-lain. Adapun DPK atau disebut sebagai Wadiah adalah bentuk perjanjian bank dengan pemilik dana berupa titipan yang mana dana tersebut oleh bank bisa saja dipakai untuk mengembangkan usaha dan keuntungan bank. Namun dalam wadiah tidak ada kewajiban bank syariah memberikan imbalan pada pemilik asli dari dana tersebut. Juga pemilik dana tidak memiliki hak menuntut untuk diberi imbalan. Kalaupun bank memberikan imbalan, itu hanyalah bonus, namun bukan hak nasabah juga bukan kewajiban bank. 


\section{KESIMPULAN}

Dari temuan hasil penelitian, dapat disimpulkan: a) DPK berpengaruh secara signifikan terhadap Laba pada Bank Syariah Mandiri periode 2012-2019. Hal ini dapat dilihat pada hasil uji t (parsial) variabel X1 (DPK) diperoleh t hitung lebih besar dari pada $t_{\text {tabel }}(2,420>2,045)$. Dengan demikian terbukti bahwa DPK berpengaruh terhadap Laba. Berdasarkan uji koefisien determinasi R Square, DPK memberikan sumbangan pengaruh terhadap Laba sebesar 9,4\%; b) Ekuitas berpengaruh signifikan terhadap Laba pada Bank Syariah Mandiri. Hal ini dapat dilihat pada hasil uji t (parsial) variabel X2 (Ekuitas) diperoleh thitung lebih besar daripada $t_{\text {tabel }}(2,825>2.045)$, dengan nilai signifikansi lebih kecil dari 0,05 $(0,008<0,05)$. Dengan demikian terbukti bahwa Ekuitas berpengaruh terhadap Laba, Berdasarkan hasil uji koefisien determinasi R Square dan Ekuitas memberikan sumbangan pengaruh terhadap Laba sebesar 16\%; c) DPK dan Ekuitas berpengaruh signifikan terhadap Laba pada Bank Syariah Mandiri periode 2012-2019, Sehingga apabila semakin besar jumlah DPK dan Ekuitas maka laba bersih juga akan meningkat. Hal ini dapat dilihat pada hasil uji $\mathrm{F}($ simultan) diperoleh Fhitung lebih besar daripada $\mathrm{F}_{\text {tabel }}(4,939>3.328)$ dengan nilai signifikansi lebih kecil daripada 0.05 ( $0.014<0.05$ ). Berdasarkan hasil uji determinasi $\left(\mathrm{R}_{2}\right)$, besarnya pengaruh DPK dan Ekuitas terhadap Laba Bank Syariah periode 2012-2019 sebesar 25,4\% sedangkan sisanya sebesar 74,6\% dipengaruhi variabel lainnya yang tidak diteliti dalam penelitian ini.

\section{REFERENSI}

Abi Abdillah Muhammad ibn Ismail ibn Ibrahim Ibnu al-Mugoirah ibn Bardizbah al-Bukhari al-Ja"efiyyi, Shahih Bukhari. Juz IV Beirut: Dar al-Fikr, 1401 H/ 1981M.

Ahmad, Beni. 2008. Metode Penelitian. Bandung: Pustaka Setia. Ali, Zainuddin. 2010. Hukum Perbankan Syariah. Jakarta: Sinar Grafika.

Antonio, Muhammad Syafie i. 2011. Bank Syariah dari Teori ke Praktik. Jakarta: Gema Insani.

Arifin, Zainul. 2002. Dasar-dasar Manajemen Bank Syariah. Jakarta: Alfabeta. Ascarya. 2013. Akad dan Produk Bank Syariah. Jakarta: Rajawali.

Azwar, Saifudin. 2001. Metode Penelitian. Yogyakarta: Pustaka Pelajar Offset.

Departemen Agama Republik Indonesia. 2009. Al-Quran dan Terjemahannya. Bandung: Sygma.

Ekawati, Mardhiyyah Fitria. Pengaruh Pembiayaan, Penempatan Dana Pada BI, Penempatan Dana Pada Bank Lain, Modal Disetor, Dan Dana Pihak 
Ketiga Terhadap Laba Bank Umum Syariah Di Indonesia. Surabaya: Universitas Airlangga, 2010.

Fees, Reeve, Warren. 2005. Pengantar Akuntansi Edisi 21. Jakarta: Salemba Empat.

Ghozali, Imam. 2005. Analisis Multivariate dengan Program SPSS. Semarang: UNDIP.

Harahap, Sofyan Syafri. 2010 Analisis Kritis atas Laporan Keuangan, Jakarta: Rajawali Pers.

Husaeni, Uus Ahmad. "The Variables Effects of Murābahah in Islamic Commercial Banks." International Journal of Nusantara Islam, vol. 4, no. 2 (2016). 1-16.

Husaeni, U.A. (2017). Determinan Pembiayaan Pada Bank Pembiayaan Rakyat Syariah di Indonesia. Esensi: Jurnal Bisnis dan Manajemen, Vol. 7 (1): 49-62.

Husaeni, U. A. (2018). Determinants Of Capital Structure In Companies Listed. International Journal of Economics, Management and Accounting 26, 2(2), 443-456.

Husaeni, Uus Ahmad, 2017. Analisis Pengaruh Dana Pihak Ketiga dan Non Performing Financing Terhadap Return On asset pada BPRS di Indonesia. Jurnal Ekonomi Syariah, Volume 5 (1), 2017, 1-16.

Ismail. 2011. Perbankan Syariah. Jakarta: Kencana.

Jumingan. 2009. Analisa Laporan Keuangan. Jakarta: Bumi Aksara.

Karim, Adiwarman. 2010. Bank Islam: Analisis Fiqih dan Keuangan. Cetakan ke7. Jakarta: Raja Grafindo Persada.

Kasmir. 2014. Dasar-Dasar Perbankan-Edisi Revisi 2014. Cetakan kedua belas, Jakarta: Rajawali Pers.

Kementerian Agama RI. 2011. Al Qur"an dan Tafsirnya. Edisi yang disempurnakan, Jilid 9. Jakarta: Widya Cahaya.

Mardani. 2014. Hukum Bisnis Islam. Jakarta: Kencana.

Kuncoro, Mudrajad dan Suhardjono. 2002. Manajemen Perbankan: Teori dan Aplikasi.Yogyakarta: BPFE.

Muhammad. 2004. Teknik Perhitungan Bagi Hasil dan Profit Marjin pada Bank Syariah. Yogyakarta: UII Press.

Muhammad. 2002. Manajemen Bank Syariah. Yogyakarta: UPP AMP YKPN.

Muslich, Ahmad Wardi. 2010. Fiqh Muamalat. Jakarta: Amzah.

M. Sulham dan Siswanto, Elly. 2008. Manajemen Bank: Konventional dan Syariah. Malang: UIN-Malang Press.

Aswawi, Nur dan Masyhuri (ed.). 2009. Metodologi Riset Manajemen Pemasaran. Malang: UIN-Malang Press.

Rahman, Afzalur. 1995. Doktrin Ekonomi Islam. Jld I. Yogyakarta: Dana Bhakti Wakaf.

Rivai, Veithzal. 2007. Bank and Financial Institute Management. Jakarta: Raja Grafindo Persada.

Sjahdeini, Sultan Remy. 2014. Perbankan Syariah Produk-Produk dan AspekAspek Hukumnya. Jakarta: Kencana.

Stice, dkk. 2004. Akuntansi Intermediate. Edisi Lima Belas, Buku I. Jakarta: Salemba Empat.

Suliyanto. 2011. Ekonometrika Terapan. Yogyakarta: ANDI. 
Sukirno, Sadono, dkk. 2012. Pengantar Bisnis. Jakarta: Prenada.

Supriyono. 2002. Akuntansi: Manajemen dan Keuangan. Edisi 1. Yogyakarta: BPFE.

Sutanto, Herry dan Umam, Khaerul. 2013. Manajemen Pemasaran Bank Syariah. Bandung: Pustaka Setia.

Suwardjono. 2008. Teori Akuntansi: Perekayasaan Pelaporan Keuangan. Yogyakarta: BPFE.

Uman, Khotibul. Trend Pembentukan Bank Umum Syariah Pasca UU No. 21 Tahun 2008 (Konsep, Regulasi dan Implementasi). Edisi 1. Yogyakarta: BPFE, 2009.

Umar, Husein. Metode Penelitian untuk Skripsi dan Tesis Bisnis. Jakarta: Grafindo Persada, 2011.

Veithzal Rivai dan Andria Permata Veithzal. 2008. Islamic Financial Management. Jakarta: Raja Grafindo Persada. 